\title{
A Cultural Contingency Model of the Effects of Leader-Society Value Congruence
}

\author{
Ghulam Mustafa ${ }^{1} \&$ Rune Lines ${ }^{1}$ \\ ${ }^{1}$ Department of Strategy and Management, NHH-Norwegian School of Economics, Bergen, Norway \\ Correspondence: Ghulam Mustafa, Department of Strategy and Management, NHH-Norwegian School of \\ Economics, Hellevein 30, 5045 Bergen, Norway. Tel: 47-559-59-244. E-mail: ghulam.mustafa@nhh.no
}

Received: July 31, 2013

Accepted: August 7, 2013

Online Published: September 23, 2013

doi:10.5539/ibr.v6n10p1

URL: http://dx.doi.org/10.5539/ibr.v6n10p1

\begin{abstract}
Previous research on cross-cultural leadership has examined the effects of leadership-society congruence without explaining how positive outcomes might result when there is a fit between leadership and societal culture, and via which mechanisms the effects of such congruence are transmitted. We fill this gap by developing a culturally contingency model of leader-society value congruence effects. First, we provide an account of the mechanisms that help understand the relationships between leader-society value congruence and outcomes. Next, we develop propositions to suggest how differences in societal values provide bases for predicting the strength of these mediating mechanisms.
\end{abstract}

Keywords: societal culture, cultural values, value congruence, leadership, leader-society congruence

\section{Introduction}

Cross-cultural leadership research has long recognized that managerial processes and leadership styles are expected to be differentially effective depending on congruency with the societies' culture (Dorfman, Javidan, Hanges, Dastmalchian, \& House, 2012; Elenkov, 1998; Hofstede, 2001; Javidan, Dorfman, de Luque, \& House, 2006; House, Wright, \& Aditya, 1997; Pasa, Kabasakal, \& Bodur, 2001; Robert, Probst, Martocchio, Drasgow, \& Lawler, 2000; Schuler \& Rogovsky, 1998). As such, behavior that is reflective of collective values will be more acceptable and effective than behavior that represents conflicting values. More specifically, it has been argued that the congruency between leadership behaviors and the societal norms and expectations is an important determinant of the leadership success (Dorfman, Sully de Luque, Hanges, \& Javidan, 2010). Together, these studies suggest that leadership factors that are consistent with societies' norms and expectations tend to be evaluated favorably.

Although numerous studies have examined relationships between leadership-society congruence, the major focus of these studies, however, has been on evaluating the degree of practice-culture fit and its outcomes without explaining how these relationships are produced. Thus, little is known about how positive outcomes might result when there is a fit between leadership and societal culture, and via which mechanisms the effects of such congruence are transmitted. There are a few attempts to explain the leadership-society congruity effects, but they are scattered and incomplete (e.g., Byrne, 1971; Hofstede, 1980; Kluckhohn, 1951; Thomas \& Ravlin, 1995; Thomas \& Toyne, 1995). Nonetheless, a closer look at this body of work reveals that various mechanisms, i.e., interpersonal attraction, predictability, and interpersonal communication (Edwards \& Cable, 2009; Meglino \& Ravlin, 1998) that provide the basis for understanding the relationships that link value congruence to outcomes might also account for the effects of leader-society congruence. This suggests that the focus of cross-cultural leadership research need not be limited to practice-culture fit, because followers who are subject to managerial processes and leadership behaviors are affected more by what they sense than by what they see and hear $(\mathrm{Fu}$, Tsui, Liu, \& Li, 2010). In fact, the degree of congruence between the culturally determined values of followers and their leader's values may be significantly related to the follower positive work outcomes. The studies by Jung and Avolio (2000) and Meglino, Ravlin, and Adkins (1989) reveal that value congruence between followers and their leaders positively influence follower outcomes, such as satisfaction and commitment. Thus, the models that assess leader-society value congruence along certain cultural dimensions, may be even more useful in understanding and explaining the relationships between leadership-culture fit and follower reactions in different national settings. 
In this article, we draw on the concept of value congruence to provide explanations of leader-society value congruence effects. Building on the existing literature, we assert that the congruence between the leader's and societal values, or in other words the culturally determined values of followers, is crucial for leadership success. Next, we spell out a cultural contingency perspective to suggest that the strength of the processes that mediate the linkage between leader-society value congruence and outcomes is not acontextual, rather it varies according to the differences in societies' values. We draw on the existing literature to provide insights into a theoretical rationale for the variance of these relationships and argue that the strength of processes by which leadership-culture congruence leads to outcomes tends to be relatively inconsistent across cultures.

The present study attempts to extend the cross-cultural leadership literature in several ways. The study underscores the importance of addressing the issue of leadership-culture congruity from the perspective of values, and brings in the concept of value congruence to provide a conceptual clarification of how the effects of leader-society value congruence tend to manifest via their impact on certain mediating constructs. Theoretically, our framework takes the cross-cultural leadership literature a step forward, given that there have been negligible attempts to clarify the processes that potentially transmit the effects of leader-society congruence on outcomes, and little attention has been paid to explain whether the strength of these mechanisms is static, or varies according to the cultural profile of a particular society. Our conceptual framework gives a more sophisticated view of the interaction effects of societal level values and mediating mechanisms to predict how positively the leader-society value congruence will be related to communication between leader and followers, the degree of leader predictability, and the degree of leader attraction in different cultural settings.

\section{A Value Congruence Perspective of the Culturally Congruent Leadership}

A substantial volume of cross-cultural leadership and management research has underscored the importance of congruence between leadership factors and the societal norms and values (House et al., 1997; Javidan \& House, 2001; Newman \& Nollen, 1996; Pillai, Scandura, \& Williams, 1999). This body of research, however, has not conceptually clarified the issue of how leader-society congruence affects leadership success within and across cultures. Addressing the issue of congruity from the perspective of values may extend our understanding of the underlying processes that potentially transmit the effects of congruence between leadership and societal culture, and it may help explain whether the strength of these mechanisms is invariant, or is subject to the values associated with a national society.

The above is important for the following reasons: firstly, for leaders to leverage the positive effects of their leadership, followers expect them to hold values and play leadership roles that are consistent with the societies' values in which they are embedded. Conversely, followers will respond negatively when the leader engages in behavior, but holds values that are different from expected, i.e., the values followers expect leaders to hold do not reflect the prevalent societal norms (Fu et al., 2010; Parsons \& Shils, 1951). The less congruence followers perceive between their own and the leader's cultural values, the less they will have positive outcomes at the workplace (e.g., Adler, 1997). Referring to implementation of self-management related changes in a cross-cultural setting, Kirkman and Shapiro (1997) assert that change targets resist change initiatives if they perceive less congruence between their own values and those of the change managers.

Secondly, it is argued that the salience of attributes change over time as people interact with each other. That is, attributes that can be readily and easily detected become less important in tying people together, because people gradually shift their focus on underlying attributes, such as values when they engage in close interactions (e.g. Jackson, 1996). For followers, leadership behaviors rather than leaders' cultural values may be subject to initial categorization, because behavioral discrepancy or similarity can more readily be detected than inconsistency or congruence in cultural value orientations. However, employees have keen observation skills to detect the differences in values, and are affected more by what they sense than by what they see and hear (Fu et al., 2010). Erez and Earley (1993) contend that cultural background becomes the major source of identity for employees to come together when differences arise between team members. According to many past studies, value congruence indicates a harmonious relationship between leader and subordinate and should therefore result in greater satisfaction over time and a desire to continue the relationship (Meglino et al., 1989; Posner, 1992). This suggests that leader-society value congruence will have more lasting and positive effects on employee outcomes and vice versa for discrepancy in values.

Thirdly, producing behaviors according to role expectations and situational demands in another culture is something unusual, and training behavioral adaptation tends to be challenging. This may lead to managerial behaviors that are likely to be seen as unnatural by followers, and they may attribute such efforts to insincere motives (Thomas \& Ravlin, 1995), and may respond negatively to such behaviors. Finally, leaders who attempt 
to produce culturally correspondent behaviors may pay a heavy psychological toll in the form of identity conflict if their individual values are inconsistent with the behavioral demands of the society's values in which they operate (Molinsky, 2007).

The congruity between the values held by leaders and the values prevalent in a society is important for the reason that societies vary in their emphasis on different values. For instance, the pursuit of power values is likely to be more acceptable in cultures characterized by high power distance, while pursuit of these values is less likely to be viewed favorably in societies where egalitarian values are emphasized (Schwartz, 1999). Likewise, self-enhancement and self-achievement are socially legitimate values in individualist and masculine cultures, but pursuit of such values may not be tied to moral standards in collectivist and feminine societies (e.g., Chatterjee \& Hambrick, 2007; Hofstede, 1980). The individuals who are subject to leadership will be sensitive to the leader-society value congruence, because values held by members of a society are partly a social phenomenon and as such the value systems they hold are likely to be reflective of the larger society (Hanges, Lord, \& Dickson, 2000). There is a high level consensus in cross-cultural literature (Hofstede, 1980; Javidan \& House, 2001; Schwartz \& Bardi, 2001) that societal culture influences perceptions and values of societal members, and a set of core cultural values, such as egalitarianism or power distance, collectivism or individual autonomy, and assertiveness or femininity is deeply internalized in societal members through different means of socialization.

In this backdrop it is expected that when there is congruity between leader and society's values, it will lead to perceptions of similarity by followers and they will be attracted towards such leader (Byrne, 1971). Such value congruence will help followers to predict behaviors of their managers leading to clear role expectations (Kluckhohn, 1951). Further, alignment between a leader's values and the culturally determined values of his/her followers may lead to commonality in the ways they respond to and interpret events (Hofstede, 1980), which is likely to improve the leader-follower communication interaction. This suggests that value congruence mechanisms, i.e., interpersonal attraction, predictability and interpersonal communication (Edwards \& Cable, 2009; Melingo \& Ravlin, 1998; Meglino et al., 1989) provide strong theoretical explanations for how or why leader-society value fit impacts leadership effectiveness, or in other words follower positive work outcomes. We next briefly introduce these mediating mechanisms and their potential influence on employee outcomes.

\subsection{Communication}

Value congruence is asserted to promote interpersonal communication, which refers to the extent members of an organization openly exchange information with each other using formal and informal means of interaction (Goldhaber, Porter, Yates, \& Lesniak, 1978). The underlying rationale is that people with congruent values tend to describe, classify, and interpret events by virtue of a shared frame of reference (Erdogan, Kraimer, \& Liden, 2004; Meglino \& Ravlin, 1998). This common frame helps smooth flow of information among members and mitigates any chances of misunderstandings by increasing the accuracy and easiness of interpersonal communication (Meglino et al., 1989). In their study on value diversity, Jehn, Northcraft, and Neale (1999) noted that employees feel a reduced readiness to exchange information with members with whom they have a perceived value difference. In a cross cultural environment, it has been found that value diversity decreases social integration (Kirchmeyer \& Cohen, 1992), and employees experience more communication problems with change managers with different value emphasis than those with whom employees share values (e.g., Zaltman \& Duncan, 1977). Enhanced interpersonal communication has also been found to have strong effects on employee outcomes. For instance, Edwards and Cable (2009) reported a positive relationship between communication and employee job satisfaction and organizational identification.

\subsection{Predictability}

Value congruence is argued to increase predictability, which enables people to predict how others will act or behave (Meglino \& Ravlin 1998; Schein, 1990). Predictability in interpersonal interactions promotes mutual understanding and decreases role conflict and ambiguity. As a result, people with congruent values tend to more efficiently coordinate their actions, and in interpersonal relationships they are likely to have higher levels of satisfaction (Fisher \& Gitelson, 1983; Smith, Sims, O’Bannon, \& Scully, 1994).

\subsection{Attraction}

Interpersonal attraction refers to an affective evaluation of another person (Berscheid, 1985; Byrne, 1971; Montoya \& Horton, 2004). Previous studies report that individuals are attracted to and feel comfortable with people who are similar to themselves (Byrne, 1971; Ruef, Aldrich, \& Carter, 2003). It has been observed that aside from various cognitive and demographic characteristics, shared values also lead members to be more attractive to each other (Riordan, 2000). Thus, interaction with people having congruent values will be pleasurable and conducive to mutual liking and will result in more positive outcomes, such as job satisfaction 
and organizational identification (Edwards \& Cable, 2009).

\section{Cultural Differences and the Strength of Mechanisms}

Although the above mechanisms offer an important theoretical logic to the understanding of relationships between leader-society value congruence and outcomes, how efficacious these processes are in influencing positive outcomes in different national societies is yet to be delineated. A more sophisticated view of such influence should focus on how different cultural dimensions moderate the strength of various congruence mechanisms differently. In going through the above mechanisms, one can say that not all mechanisms are uniformly salient in all cultures, rather the strength of different mechanisms vary for different cultural settings. For example, in a culture characterized by individualistic values, leader-society value congruence is less likely to be a source of 'interpersonal attraction' for subordinates, while in a culture where collectivist values are prevalent, leader-society value similarity will engender more follower liking for a leader, and thus, attraction mechanism in such cultures will be more salient in mediating the influence of leader-society value congruence on follower outcomes. To address this gap in the literature, we specify a cultural contingency perspective to argue that differences in societies' values provide bases for predicting the strength of mediating mechanisms that potentially transmit the effects of leader-society value congruence on employee work outcomes.

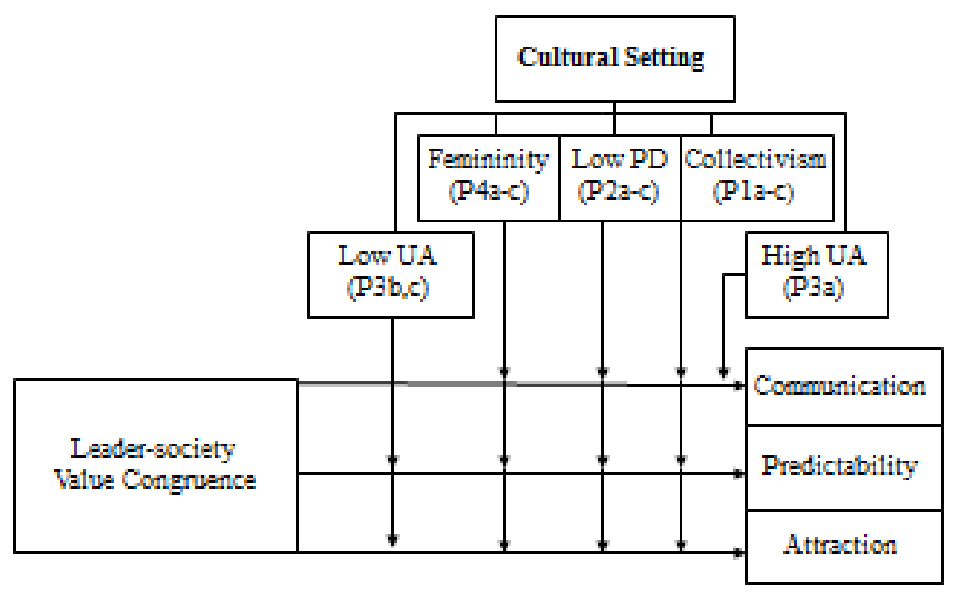

Figure 1. Conceptual framework

Figure 1 displays a hypothesized model of the relationships between leader-society value congruence, societal level culture, and mediating mechanisms. It suggests that societal values moderate the strength of mechanisms that link leadership-society value alignment with work outcomes. Hofstede's (1980) four cultural dimensions-collectivism-individualism, power distance, uncertainty avoidance, and masculinity-femininity-serve as the backdrop for understanding the leader-society value congruence effects in the context of societal culture.

\subsection{Collectivism-Individualism}

\subsubsection{Communication}

Previous studies suggest that actors experience enhanced willingness to share important information with individuals perceived as similar, and they are less inclined to engage in open sharing of information with those perceived as out-group members (Larkey, 1996). It has further been suggested that cultural differences between group members lead to breakdown in communication (Thomas, 1999), which is expected to be more apparent in collectivist cultures where group categorization is high, and people displaying cultural similarity and variability are considered as in-group and out-group members (Triandis, 1995). The above is supported by past studies that contend that employees with a low degree of group perspective are less wary about sharing information or material while working in teams, whereas employees with a salient group orientation closely interact and keep exchanging materials and information when they work as part of a team (Kirkman \& Shapiro, 1997; Rafferty \& Tapsell, 2001). This suggests that leader-society value similarity may account for a positive impact on communicative interaction between leaders and followers.

In contrast, group membership is more volatile in individualist cultures where people tend to be less attentive to any discrepancy between self and others. In social and organizational interactions, members of individualist 
societies may pay their entire attention to the task at hand and focus narrowly on cultural differences (e.g., Wang, Fussel, \& Setlock, 2009). Thus, a high degree of leader-society value congruence may not have a significant impact on enhanced communication between leader and subordinates.

\subsubsection{Predictability}

People in collectivist cultures have a tendency to see their self from a holistic perspective and attach greater importance to group over individual interests (Hofstede, 1980; 2001). Norms in such cultures reflect social interdependence and mutual obligation among members, and individuals follow in-group guidelines for socially acceptable behavior (Triandis, 1998; Ueno \& Sekaran, 1992). Cultural characteristics of high interdependence and mutual obligation warrant members of such societies to understand their roles and to do what is socially correct and proper. Leaders are more likely to adopt a team oriented style; they tend to build consensus in decision making, and emphasize interdependence rather than promoting or pursuing independent agendas (Chan \& Drasgow, 2001; Mead, 1993). Leaders may be aware of the social implications associated with deviant behaviors and tend to follow the established norms while working towards organizational goals.

In individualist societies autonomy of a person is considered as more important than his/her obligations to the in-group (Schwartz, 1999), which indicates that cultures characterized by individualist values allow ample latitude in human behavior (Kale \& McIntyre, 1991). Organizations located in individualist societies are tolerant of variance in behavior, meaning that individual members in such societies are treated as autonomous actors and the freedom of thought and behavior on their part is encouraged (Sagiv \& Lee, 2006). The above suggests that collectivist values emphasize human behaviors that reflect low degrees of variance and greater stability and conformity, while individualist values support distinctiveness and idiosyncrasy which promote behavior patterns that tend to be less predictable (Doney, Cannon, \& Mullen, 1998). Thus, high leader-society value congruence in collectivist societies means that future actions and behaviors of such leaders would be predictable, while in individualistic societies it will be less easy for followers to predict a leader's future behavior regardless of a high cultural congruence on the part of such leader.

\subsubsection{Attraction}

In collectivist societies high group distinctions exist, which can be seen in greater social liking for in-group members (Hogg, 2001) and mistrust towards out-group members (Fukuyama, 1995). Further, people in such cultures are likely to make sharp emotional distinctions between in-group and out-group members (Earley, 1989) and make a positive evaluation of the in-group members (Gomez, Kirkman, \& Shapiro, 2000). Chen and Li's (2005) study revealed that individuals from collectivist cultures (Hong Kong) are more cooperative with in-group members, while they have a lesser tendency to trust and cooperate with out-group members. Ellemers, de Gilder, and Haslam (2004) argue that when employees perceive their managers as in-group members, they expect the intentions and motives of such managers to be sincere. This suggests that in collectivist cultures, a high leader-society value similarity would elicit an affective subordinate evaluation of leaders, because high leader-society value congruence predisposes that the attributes of such leaders typify the characteristics seen as prototypical of in-group members.

In individualistic cultures, in-group/out-group distinctions are not salient (Oyserman, Coon, \& Kemmelmeier, 2002). The reason such categorization is not evident in individualist societies is that people in such cultures accord high importance to personal interests over group affiliation (Gelfand, Bhawuk, Nishi, \& Bechtold, 2004). In fact, people with individualist tendencies carefully evaluate the pros and cons of every transaction and look for the best deal they can get (Ting-Toomey, 1994; Triandis, 1995). This suggests that for employees embedded in individualist cultures, the motivation to work with a leader seems to be governed by a transactional process of employee effort in exchange for material gains (Walumbwa, Lawler, \& Avolio, 2007). Employees in such cultures tend to be happy so long as a leader offers them benefits proportionate to their individual performance, no matter to what extent such leader's values are congruent with the larger society. This leads us to conclude that a manager who holds values that are compatible with societal values would emerge as a greater source of attraction for followers in collectivist cultures than in societies characterized by individualist values. Consequently, we suggest the following:

P1a. On average, the leader-society value congruence will be more positively related to communication between leader and followers in a collectivist culture than in an individualist culture.

P1b. On average, the leader-society value congruence will be more positively related to the degree of leader predictability in a collectivist culture than in an individualist culture.

P1c. On average, the leader-society value congruence will be more positively related to the degree of leader 
attraction in a collectivist culture than in an individualist culture.

\subsection{Power Distance (PD)}

\subsubsection{Communication}

The strong emphasis of high PD societies on vertical orientation leads to role diversity in organizational hierarchy making superiors distant from followers, which restricts interpersonal communication between leaders and employees (Roberts \& O'Reilly, 1979). Kirkbridge, Tang, and Westwood (1991) argue that in vertical societies people are very sensitive to the status of the other party in the exchange relationship, meaning that there is a lesser degree of communication between incumbents of different hierarchical levels. Evidence from the Indian cultural context suggests that in Indian organizations, role differentiation is an important determinant of communication between junior and senior employees. In India, employees in subordinate positions are expected to be aware of their own place in the hierarchy, and they strictly follow norms related to senior-junior relationships when they need to approach their bosses (Zaidman \& Brock, 2009). Jaeger (1986) contends that team building is a less effective management initiative in such cultures, because members from different hierarchical levels feel uncomfortable in interacting face-to-face in a group and engage in little communicative interaction with each other.

Conversely, in low PD societies hierarchy is not the primary concern, which leads to physical proximity between superiors and subordinates. Prior studies suggest that decreased hierarchical distance improves the quality of communication between managers and employees (Chen \& Bliese, 2002). Leaders in low PD cultures seek wide participation in decision-making, and employees are eager to convey their ideas and opinions directly to their managers (Elenkov, 1998). This supports a consultative leadership style with open and frank communication between superiors and subordinates (Selmer \& De Leon, 1996).

\subsubsection{Predictability}

In high PD societies, superiors take charge of the affairs, while those who occupy low ranks in the hierarchy are in the position to obey. Superiors in such cultures wield high authority (Farh \& Cheng, 2000), force action as they deem fit, and at times keep information secret from subordinates (Spreitzer, Perttula, \& Xin, 2005). The leaders' actions in such societies tend to be directed towards achieving personal interests through gaining control over people and resources. This suggests high latitude for variability in leader behavior that provides subordinates with little evidence that their leader's future actions and behavior will be predictable.

In low PD cultures, employee-management relationships are built on the principles of cooperative negotiation (Sagiv \& Lee, 2006). Leaders enjoy little discretionary powers and take subordinates on board in making decisions and setting goals. As a result, high leader-society value congruence in a low PD setting will facilitate the followers' ability to predict the leader behavior.

\subsubsection{Attraction}

Power distance norms appear to foster dependency-based relationships between superiors and subordinates, whereby beliefs of power inequalities render subordinates to continue accepting their leaders' perspective (Bochner \& Hesketh, 1994; Javidan et al., 2006). Chew and Putti (1995) contend that high PD values promote duty-bound loyalties in relationships, and individuals who value hierarchy are less likely to develop feelings of affective attachment to targets, and they stay in existing relationships because of the perceived social appropriateness. Prior studies (Ryan \& Deci, 2003) contend that practices such as submitting to authority tend to involve poor psychological functions of supporting one's well-being. However, related to such practices there are norms which tend to force people to subjugate their own ideas to those of the people in authority. Thus, it is hard to expect that followers in hierarchical cultures will develop an emotional or affective attachment to a leader who strongly espouses high PD values.

Contrary to duty-bound loyalties in hierarchical societies, cooperation and mutual support form the basis of relationships in low PD cultures. Norms in such cultures support participative decision making (Elenkov, 1998), and leaders adopt goals and behaviors that promote equality, empowerment and employee well-being (e.g., Sagiv \& Lee, 2006). This suggests that managers and employees in egalitarian cultures will engage in a relationship that is driven by an internal feeling of sincerity, which in turn will lead to a sense of mutual liking. The above leads us to propose the following:

P2a. On average, the leader-society value congruence will be more positively related to communication between leader and followers in a low PD culture than in a high PD culture.

P2b. On average, the leader-society value congruence will be more positively related to the degree of leader 
predictability in a low PD culture than in a high PD culture.

P2c. On average, the leader-society value congruence will be more positively related to leader attraction in a low PD culture than in a high PD culture.

\subsection{Uncertainty Avoidance (UA)}

\subsubsection{Communication}

Societies that score high on uncertainty avoidance tend to establish detailed processes, procedures, and strategies, leaving less room for flexibility (House et al., 2004). Individuals in such societies place greater value on tested patterns of behavior that makes them more risk averse and less accustomed to innovative behavior (Hofstede, 2001). At the workplace, high proclivity for risk avoidance is reflected in too much reliance on task clarification. The need for excessive task clarification makes it difficult to take initiatives that run counter to workplace norms and normal organizational routines (e.g., Hofstede, 1984). Past research (Kets, de Vries, \& Miller, 1986; Hambrick \& Brandon, 1988) indicates that managers of high UA cultures are comfortable with a more stable environment, while managers from low UA cultures are averse to a conservative intra-organizational environment. This suggests that managers in high UA cultures lack an innovative spirit, and they expect their followers to focus on what is specified in their respective job descriptions (Mead, 1993). The strict emphasis on formalized working may create an organizational environment that decreases motivation of both managers and subordinates to engage in communicative interaction with each other.

In contrast, societal cultures that score low on uncertainty avoidance tend to prefer simple processes and broad strategies, leaving room for flexibility and risk taking (House et al., 2004). Managers from low UA cultures emphasize new initiatives (Hambrick \& Brandon, 1988) and tend to expect from their subordinates flexibility to changes and a proactive and entrepreneurial behavior. This stimulates innovative thinking and exchange of information leading to increased interpersonal communication between superiors and subordinates.

\subsubsection{Predictability}

In high UA societies, clear rules and norms guide behavioral patterns and social interactions (Hofstede, Hofstede, \& Minkov, 2010; Reisinger \& Turner, 2003). That is, in such cultures a great importance is attached to predictable behavior (Kale \& McIntyre, 1991), and variability in relationships is discouraged. Chew and Putti (1995) support this view by providing evidence that individuals high on UA values prefer to build relationships that are stable and enduring. Many past studies (Hambrick \& Brandon, 1988; Laurent, 1983) investigate the relationship of UA values and managerial preference for stability/risk avoidance and posit that managers from high UA cultures have a high propensity for a stable and predictable organizational environment.

On the other hand, low UA societies place greater value on newness and change, and embrace difference of opinions and a wide behavioral heterogeneity (Kale \& Barnes, 1992). Individuals with a low UA orientation are reported to form short-term and multiple commitments and tend to have less employment stability (Chew \& Putti, 1995; Stewart, Barsoux, Kieser, Ganter, \& Walgenbach, 1994). This leads us to infer that leader behavior in high UA cultures will be more predictable, whereas followers in low UA cultures will find it difficult to predict leader behavior regardless of a high cultural congruence on the part of such leader.

\subsubsection{Attraction}

In high UA cultures, people feel comfortable in environments that facilitate risk avoidance and limit fear of ambiguity (Hodson \& Sorrentino, 2001; Shuper, Sorrentino, Otsubo, Hodson, \& Walker, 2004). In view of the perceived security associated with preserving the current arrangements, organizational members in such cultures tend to maintain existing relationships, value compromise and avoid conflict at the workplace. Smith's (2004) research shows that people in UA cultures adopt acquiescent response behaviors, which emphasize agreeableness and modesty in interaction with others (Javeline, 1999). These dynamics may result in an employee's attachment to a leader or an organization whose goals and practices promote security expectations and mitigate the chances of an unseen loss.

In contrast, people in low UA societies are more concerned about the outcome of a behavior than adherence to the norms of wider societal approbation (Yan \& Hunt, 2005). Conflict in such cultures is acceptable, and individuals show no reluctance to swap relationships for potential beneficial outcomes (Doney et al., 1998). This is why leader-subordinate relationships in low UA societies tend to be task-oriented and less durable, because they are not guided by motives that lead to affective evaluation of targets. This suggests that followers will make a positive evaluation of a leader who espouses high UA values; while there is no indication that a manager in low UA cultures will elicit an affective feeling from followers merely on the basis of his/her value congruity with the societal culture. Based on the above, we suggest the following: 
P3a. On average, the leader-society value congruence will be more positively related to communication between leaders and followers in a low UA culture than in a high UA culture.

P3b. On average, the leader-society value congruence will be more positively related to the degree of leader predictability in a high UA culture than in a low UA culture.

P3c. On average, the leader-society value congruence will be more positively related to the degree of leader attraction in a high UA culture than in a low UA culture.

\subsection{Masculinity-Femininity}

\subsubsection{Communication}

In general, individuals in masculine societies are achievement-oriented and they pursue success in material gains (Hofstede, 1980; Kale \& Barnes, 1992). A success-oriented drive that typifies masculine cultures may render individuals to adopt a self-centered approach and take a more proactive role in individual than group level processes. It, thus, restricts interdependence through contingencies such as limited trust and communication. Conversely, people embedded in feminine cultures tend to adopt a nurturant, participative and team-oriented style, and express greater emotional sensitivity for others (Hofstede, 1998; Schuler \& Rogovsky, 1998), which tends to foster a strong feeling of a psychologically secure environment where individuals feel comfortable to engage in open and frank communication. This implies that high leader-society value congruence will lead to enhanced communication between leader and subordinates in feminine cultures, while in masculine societies it will have no significant effect.

\subsubsection{Predictability}

In masculine societies, high performance and achievement are at the core of one's preferences (Kale \& Barnes, 1992), and people place less emphasis on maintaining social relationships (Hofstede, 1984). This supports divergence of thought and action to a great extent, and thus, a high degree of behavioral discrepancies are expected in such societies. Evidence from organizational context suggests that managers in masculine cultures are likely to have a strong concern for results (Geletkanycz, 1997), and they tend to advocate change in the status-quo if such an alteration is expected to yield benefits (Aldrich, 2006). In contrast, high importance is ascribed to maintaining stable and friendly relationships in feminine societies (Hofstede, 1984; Lam, Lee, \& Mizerski, 2009). The focus of feminine cultures on nurturing and preserving the interpersonal ties may encourage behavioral conformity, and restrict the chances of behavioral anomalies. This suggests that in masculine societies, high leader-society value congruence may not make it easier for followers to predict the future behavior of the leader, while in a feminine society it will be consistent with the notion of predictable behavior.

\subsubsection{Attraction}

People in masculine societies tend to be less concerned about the needs and interests of others than their own success and advancement. Earlier studies support this view by arguing that a masculine orientation is manifest in transaction of efforts for extrinsic rewards (O'Reilly \& Chatman, 1986), and people high on masculinity build relationships based on calculative commitments (Randall, 1993). Thus, high leader-society value congruence will not be a source of great attraction for followers in masculine societies because 1) subordinates' interests may not be at the heart of a prototypical leader, and 2) subordinates are more pragmatic (Rakos, 1991) about the costs and benefits of social relationships; they tend to perceive a leader-follower relationship as attractive so far as such a relationship has beneficial impact on their drive for extrinsic rewards.

In feminine societies, nurturance, modesty, and tenderness take precedence over a quest for acquiring material things (Hofstede, 2001). Affective commitment rather than calculative assessment of benefits determine the basis of relationships in such societies (Randall, 1993). Organizations in feminine societies place greater value on employee welfare, and employees positively react to leadership and managerial processes that promote employee well-being in both work and non-work domains (Jackson \& Schuler, 1995). This is in line with earlier findings that suggest that a high level of warmth linked to leadership is important in feminine societies, such as Norway (Hetland \& Sandal, 2003). Employees in feminine cultures are therefore expected to have a greater attraction to leaders who display a high cultural congruence, because the intentions of such leaders are likely to be sincere with regards to promoting the socio-emotional well-being of subordinates. Based on the above, we suggest the following:

P4a. On average, the leader-society value congruence will be more positively related to communication between leaders and followers in a feminine culture than in a masculine culture. 
P4b. On average, the leader-society value congruence will be more positively related to the leader predictability in a feminine culture than in a masculine culture.

P4c. On average, the leader-society value congruence will be more positively related to the degree of leader attraction in a feminine culture than in a masculine culture.

\section{Implications for Research and Practice}

\subsection{Limitations and Directions for Future Research}

In going through the three value congruence mechanisms, our model posits that some cultures promote 'interpersonal attraction', 'predictability' and 'interpersonal communication' more than other cultures. But, in view of the earlier belief that leader-society congruence may be invariant across culture (House et al., 1997), future research might propose competing mechanisms for competing cultural dimensions to present a more sophisticated view of the means and processes by which value congruence leads to employee outcomes across different societal contexts. For instance, we propose that 'interpersonal attraction' will evoke higher levels of performance in feminine cultures than in masculine societies, we defer the question of whether 'interpersonal attraction' may operate through two different bases, i.e., cognitive and affective, and attraction in feminine societies is an affect-based process, while a rationality driven attraction elicits more positive outcomes in masculine cultures.

In our conceptual framework, the focus of discussion has been on the influence of societal culture from a unidimensional perspective. However, a more pragmatic approach is that all national cultures embody multidimensional characteristics and each cultural dimension may be high, low, or moderate in terms of its intensity, and the way the strength of different mechanisms is expressed is the result of the combined influence of all cultural dimensions that constitute the value constellation of a particular national culture. Thus, the strength of each mechanism may depend upon how cultural values may interact with each other. Theorizing the effect of and testing such interactions would likely make a valuable theoretical contribution to a more holistic understanding of the effect of cultural values on the strength of mediating mechanisms in different cultural settings. Further, future research might explore interaction effects of the proposed mechanisms on follower outcomes in addition to testing the model for the main effects of the mechanisms.

Although, the moderating effects of culture in our framework are conceptualized at the national level, such an influence is also extendable to the individual or group level of analysis. This is in line with earlier assertion that the construct of culture need not be limited to societal level of analysis. For instance, individual level cultural values have been reported to play an important role in shaping follower reactions to leadership and other aspects of their work (Gelfand, Erez, \& Aycan, 2007; Kirkman, Chen, Farh, Chen, \& Lowe, 2009; Walumbwa et al., 2007), which suggests that the strength of a given mechanism may depend on follower's individually held cultural values. Likewise, it has been asserted that all work teams develop distinctive cultures (Levine \& Moreland, 1991), and many studies have examined cultural constructs at group levels of analysis, such as work teams (Kirkman \& Shapiro, 2001; Schaubroeck, Lam, \& Cha, 2007). As a consequence, our propositions for moderating effects of culture, which we have conceived at the societal level, can also be tested at the individual and group level of analysis.

\subsection{Practical Implications}

This framework can be helpful to organizations in carrying out selection of managers for different countries based on how effective are the mechanisms, i.e., interpersonal communication, predictability, and interpersonal attraction, in different societal contexts. The salience of these mechanisms in certain cultural settings suggests that employees are sensitive to the congruence between the values possessed by the leaders and the wider societal expectations. Thus, followers in such cultures are likely to view leaders' incongruent values more negatively than leaders' external behaviors. For selecting managers for such countries, it is important that managers be assessed for their individual level cultural values, and those managers be selected whose values are closely linked with the societal values of the host culture. One important benefit of such selection will be that such managers will work in the foreign country without suffering an identity conflict as a result of incompatibility between their individual values and the newly encountered societal norms. In cultures, where these mechanisms are not effective, managers should be selected based on how adept they are in adapting their behaviors overseas rather than assessing their value compatibility with the host culture. The logic is that followers in such cultural contexts may be more tolerant or may react less negatively to discrepancy between leader-society values. They tend to be more attentive to readily observable attributes, such as external behavior and motivational practices, than to detecting how the deep seated values of leaders are consistent with societal norms and values. 


\section{References}

Adler, N. J. (1997). International dimensions of organizational behavior. Cincinnati, Ohio: South-Western College Publishing.

Aldrich Howard, E. (2006). Organizations evolving. Thousand Oaks, CA: Sage.

Berscheid, E. (1985). Interpersonal attraction. In G. Lindzey \& E. Aronson (Eds.), Handbook of Social Psychology (pp. 413-484). New York: Random House.

Bochner, S., \& Hesketh, B. (1994). Power distance, individualism/collectivism, and job-related attitudes in a culturally diverse work group. Journal of Cross-Cultural Psychology, 25(2), 233-257. http://dx.doi.org/10.1177/0022022194252005

Byrne, D. E. (1971). The attraction paradigm. New York: Academic Press.

Chan, K. Y., \& Drasgow, F. (2001). Toward a theory of individual differences and leadership: understanding the motivation to lead. Journal of Applied Psychology, 86(3), 481-498. http://dx.doi.org/10.1037/0021-9010.86.3.481

Chen, G., \& Bliese, P. D. (2002). The role of different levels of leadership in predicting self and collective efficacy: evidence for discontinuity. Journal of Applied Psychology, 87(3), 549-556. http://dx.doi.org/10.1037/0021-9010.87.3.549

Chew, I. K. H., \& Putti, J. (1995). Relationship on work-related values of Singaporean and Japanese managers in Singapore. Human Relations, 48(10), 1149-1170. http://dx.doi.org/10.1177/001872679504801003

De Vries, M. F. K., \& Miller, D. (1986). Personality, culture, and organization. Academy of Management Review, 11(2), 266-279. http://dx.doi.org/10.2307/258459

Doney, P. M., Cannon, J. P., \& Mullen, M. R. (1998). Understanding the influence of national culture on the development of trust. Academy of Management Review, 23(3), 601-620.

Dorfman, P. W., Sully de Luque, M., Hanges, P., \& Javidan, M. (2010). Strategic Leadership Across Cultures: The New GLOBE Multinational Study. Paper presented at the Academy of Management annual meeting, Montreal, Canada.

Earley, P. C. (1989). Social loafing and collectivism: A comparison of the United States and the People's Republic of China. Administrative Science Quarterly, 34(4), 565-581. http://dx.doi.org/10.2307/2393567

Edwards, J. R., \& Cable, D. M. (2009). The value of value congruence. Journal of Applied Psychology, 94(3), 654-677. http://dx.doi.org/10.1037/a0014891

Elenkov, D. S. (1998). Can American management concepts work in Russia. California Management Review, 40(4), 133-156. http://dx.doi.org/10.2307/41165968

Ellemers, N., De Gilder, D., \& Haslam, S. A. (2004). Motivating individuals and groups at work: A social identity perspective on leadership and group performance. Academy of Management Review, 29(3), 459-478.

Erdogan, B., Kraimer, M. L., \& Liden, R. C. (2004). Work value congruence and intrinsic career success: the compensatory roles of leader member exchange and perceived organizational support. Personnel Psychology, 57(2), 305-332. http://dx.doi.org/10.1111/j.1744-6570.2004.tb02493.x

Erez, M., \& Earley, P. C. (1993). Culture, self-identity, and work. New York: Oxford University Press. http://dx.doi.org/10.1093/acprof:oso/9780195075809.001.0001

Farh, J. L., \& Cheng, B. S. (2000). A cultural analysis of paternalistic leadership in Chinese organizations. In J. T. Li, Tsui, A. S., \& Weldo, E. (Eds.), Management and organizations in the Chinese context (pp. 84-130). London: Macmillan.

Fisher, C. D., \& Gitelson, R. (1983). A meta-analysis of the correlates of role conflict and ambiguity. Journal of Applied Psychology, 68(2), 320-333. http://dx.doi.org/10.1037/0021-9010.68.2.320

Fu, P. P., Tsui, A. S., Liu, J., \& Li, L. (2010). Pursuit of whose happiness? Executive leaders' transformational behaviors and personal values. Administrative Science Quarterly, 55(2), 222-254. http://dx.doi.org/10.2189/asqu.2010.55.2.222

Geletkanycz, M. A. (1997). The salience of 'culture's consequences': The effects of cultural values on top executive commitment to the status quo. Strategic Management Journal, 18(8), 615-634. 
http://dx.doi.org/10.1002/(SICI)1097-0266(199709)18:8<615::AID-SMJ889>3.0.CO;2-I

Gelfand, M. J., Bhawuk, D. P. S., Nishi, L. H., \& Bechtold, D. J. (2004). Individualism and Collectivism. In R. J. House, P. J. Hanges, M. Javidan, P. W. Dorfman, \& V. Gupta (Eds.), Culture, leadership, and organizations (pp. 437-512). Thousand Oaks, CA: Sage.

Gelfand, M. J., Erez, M., \& Aycan, Z. (2007). Cross-cultural organizational behavior. Annu. Rev. Psychol., 58, 479-514. http://dx.doi.org/10.1146/annurev.psych.58.110405.085559

Goldhaber, G. M., Porter, D. T., Yates, M. P., \& Lesniak, R. (1978). Organizational communication: State of the art. Human Communication Research, 5(1), 76-96. http://dx.doi.org/10.1111/j.1468-2958.1978.tb00624.x

Gómez, C., Kirkman, B. L., \& Shapiro, D. L. (2000). The impact of collectivism and in-group/out-group membership on the evaluation generosity of team members. Academy of Management Journal, 43(6), 1097-1106. http://dx.doi.org/10.2307/1556338

Hambrick, D. C., \& Brandon, G. L. (1988). Executive values. In D. C. Hamabrick (Ed.), The executive effect: Concepts and methods for studying top managers (pp. 3-31). Greenwich, CT: JAI Press.

Hanges, P., Lord, R., \& Dickson, M. (2000). An Information - processing Perspective on Leadership and Culture: A Case for Connectionist Architecture. Applied psychology, 49(1), 133-161. http://dx.doi.org/10.1111/1464-0597.00008

Hetland, H., \& Sandal, G. (2003). Transformational leadership in Norway: Outcomes and personality correlates. European Journal of Work and Organizational Psychology, 12(2), 147-170. http://dx.doi.org/10.1080/13594320344000057

Hodson, G., \& Sorrentino, R. M. (2001). Just who favors in in-group? Personality differences in reactions to uncertainty in the minimal group paradigm. Group Dynamics: Theory, Research, and Practice, 5(2), 92-101. http://dx.doi.org/10.1037/1089-2699.5.2.92

Hofstede, G. (1980). Culture's consequences: International differences in work-related values. Beverly Hills, CA: Sage.

Hofstede, G. (1984). Cultural dimensions in management and planning. Asia Pacific Journal of Management, 1(2), 81-99. http://dx.doi.org/10.1007/BF01733682

Hofstede, G., Hofstede, G. J., \& Minkov, M. (2010). Cultures and Organizations: Software of the Mind, revised and expanded (3rd ed.). New York, NY: McGraw-Hill.

Hofstede, G. H. (1998). Masculinity and femininity: The taboo dimension of national cultures. Thousand Oaks, CA: Sage.

Hofstede, G. H., \& Hofstede, G. (2001). Culture's consequences: comparing values, behaviors, institutions, and organizations across nations. Thousand Oaks, CA: Sage.

Hogg, M. A. (2005). Social identity and leadership. In D. M. Messick \& R. M Kramer (Eds.), The psychology of leadership: New perspectives and research (pp. 53-80). Mahwah, NJ: Erlbaum.

House, R. J., Hanges, P. J., Javidan, M., Dorfman, P. W., \& Gupta, V. (2004). Leadership, culture, and organizations: The GLOBE study of 62 societies. Beverly Hills: Sage Publications.

House, R. J., Wright, N. S., \& Aditya, R. N. (1997). Cross-cultural research on organizational leadership. In P. C. Earley \& M. Erez (Eds.), New perspectives in international industrial organizational psychology (pp. 535-625). San Francisco: New Lexington.

Jackson, S. E. (1996). The consequences of diversity in multidisciplinary work teams. In M. A. West (Ed.), Handbook of work group psychology. UK: John Wiley \& Sons.

Jackson, S. E., \& Schuler, R. S. (1995). Understanding human resource management in the context of organizations and their environments. Strategic Human Resource Management, 46, 237-264.

Jaeger, A. M. (1986). Organization development and national culture: Where's the fit? Academy of Management Review, 11(1), 178-190.

Javeline, D. (1999). Response effects in polite cultures: A test of acquiescence in Kazakhstan. Public Opinion Quarterly, 63(1), 1-28. http://dx.doi.org/10.1086/297701

Javidan, M., \& House, R. J. (2001). Cultural acumen for the global manager: Lessons from project GLOBE. Organizational Dynamics, 29(4), 289-305. http://dx.doi.org/10.1016/S0090-2616(01)00034-1 
Jehn, K. A., Northcraft, G. B., \& Neale, M. A. (1999). Why differences make a difference: A field study of diversity, conflict and performance in workgroups. Administrative Science Quarterly, 44(4), 741-763. http://dx.doi.org/10.2307/2667054

Jung, D. I., \& Avolio, B. J. (2000). Opening the black box: An experimental investigation of the mediating effects of trust and value congruence on transformational and transactional leadership. Journal of

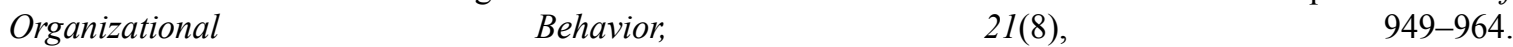
http://dx.doi.org/10.1002/1099-1379(200012)21:8<949::AID-JOB64>3.0.CO;2-F

Kale, S. H., \& McIntyre, R. P. (1991). Distribution channel relationships in diverse cultures. International Marketing Review, 8(3), 31-45. http://dx.doi.org/10.1108/02651339110004069

Kirchmeyer, C., \& Cohen, A. (1992). Multicultural Groups Their Performance and Reactions with Constructive $\begin{array}{lllll}\text { Conflict. Group } \quad \& \quad \text { Organization } & \text { Management, }\end{array}$ http://dx.doi.org/10.1177/1059601192172004

Kirkbride, P. S., Tang, S. F., \& Westwood, R. I. (1991). Chinese conflict preferences and negotiating behaviour: Cultural and psychological influences. Organization Studies, 12(3), 365-386. http://dx.doi.org/10.1177/017084069101200302

Kirkman, B. L., Chen, G., Farh, J. L., Chen, Z. X., \& Lowe, K. B. (2009). Individual power distance orientation and follower reactions to transformational leaders: A cross-level, cross-cultural examination. Academy of Management Journal, 52(4), 744-764. http://dx.doi.org/10.5465/AMJ.2009.43669971

Kirkman, B. L., \& Shapiro, D. L. (1997). The impact of cultural values on employee resistance to teams: Toward a model of globalized self-managing work team effectiveness. Academy of Management Review, 22(3), 730-757.

Kirkman, B. L., \& Shapiro, D. L. (2001). The impact of cultural values on job satisfaction and organizational commitment in self-managing work teams: The mediating role of employee resistance. Academy of Management Journal, 44(3), 557-569. http://dx.doi.org/10.2307/3069370

Kluckhohn, C. (1951). The study of culture. In D. Lerner \& H. D. Lasswell (Eds.), The Policy Sciences (pp. 86-101). Stanford, CA: Stanford University Press.

Lam, D., Lee, A., \& Mizerski, R. (2009). The effects of cultural values in word-of-mouth communication. Journal of Iternational Marketing, 17(3), 55-70. http://dx.doi.org/10.1509/jimk.17.3.55

Larkey, L. K. (1996). Toward a theory of communicative interactions in culturally diverse workgroups. Academy of Management Review, 21(2), 463-491.

Laurent, A. (1983). The cultural diversity of western conceptions of management. International Studies of Management and Organization, 13(1-2), 75-96.

Levine, J. M., \& Moreland, R. L. (1991). Culture and socialization in work groups. In L. B. Resnick, J. M. Levine \& S. D. Teasley (Eds.), Perspectives on socially shared cognition (pp. 257-279). Washington, DC: American Psychological Association. http://dx.doi.org/10.1037/10096-011

Mead, R. (1993). Cross-Cultural Management Communication. UK: John Wiley \& Sons.

Meglino, B. M., \& Ravlin, E. C. (1998). Individual values in organizations: Concepts, controversies, and research. Journal of Management, 24(3), 351-389.

Meglino, B. M., Ravlin, E. C., \& Adkins, C. L. (1989). A work values approach to corporate culture: A field test of the value congruence process and its relationship to individual outcomes. Journal of Applied Psychology, 74(3), 424. http://dx.doi.org/10.1037/0021-9010.74.3.424

Molinsky, A. (2007). Cross-cultural code-switching: The psychological challenges of adapting behavior in foreign cultural interactions. Academy of Management Review, 32(2), 622-640. http://dx.doi.org/10.5465/AMR.2007.24351878

Montoya, R. M., \& Horton, R. S. (2004). On the importance of cognitive evaluation as a determinant of interpersonal attraction. Journal of Personality and Social Psychology, 86(5), 696-712. http://dx.doi.org/10.1037/0022-3514.86.5.696

Newman, K. L., \& Nollen, S. D. (1996). Culture and congruence: The fit between management practices and national culture. Journal of International Business Studies, 27(4), 753-779. http://dx.doi.org/10.1057/palgrave.jibs.8490152 
O’Reilly, C. A., \& Chatman, J. (1986). Organizational commitment and psychological attachment: The effects of compliance, identification, and internalization on prosocial behavior. Journal of Applied Psychology, 71(3), 492-499. http://dx.doi.org/10.1037/0021-9010.71.3.492

Oyserman, D., Coon, H. M., \& Kemmelmeier, M. (2002). Rethinking individualism and collectivism: evaluation of theoretical assumptions and meta-analyses. Psychological bulletin, 128(1), 3-72. http://dx.doi.org/10.1037/0033-2909.128.1.3

Parsons, T., \& Shils, E. A. (1951). Values, motives, and systems of action. In T. Parsons \& E. A. Shils (Eds.), Toward a general theory of action (pp. 47-275). Cambrigde: Harvard University Press.

Pillai, R., Scandura, T. A., \& Williams, E. A. (1999). Leadership and organizational justice: Similarities and differences across cultures. Journal of International Business Studies, 30(4), $763-779$. http://dx.doi.org/10.1057/palgrave.jibs.8490838

Posner, B. Z. (1992). Person-organization values congruence: No support for individual differences as a moderating influence. Human Relations, 45(4), 351-361. http://dx.doi.org/10.1177/001872679204500403

Rafferty, J., \& Tapsell, J. (2001). Self-managed work teams and manufacturing strategies: Cultural influences in the search for team effectiveness and competitive advantage. Human Factors and Ergonomics in $\begin{array}{lllll}\text { Manufacturing } \quad \text { \& } & \text { Service } & \text { Industries, } & 11(1), & 19-34 .\end{array}$ http://dx.doi.org/10.1002/1520-6564(200124)11:1<19::AID-HFM2>3.0.CO;2-7

Rakos, R. F. (1991). Assertive behavior: Theory, research, and training. London: Routledge.

Randall, D. M. (1993). Cross-cultural research on organizational commitment: A review and application of Hofstede's value survey module. Journal of Business Research, 26(1), 91-110. http://dx.doi.org/10.1016/0148-2963(93)90045-Q

Reisinger, Y., \& Turner, L. (2003). Cross-cultural behaviour in tourism: Concepts and analysis. Oxford: Butterworth-Heinemann.

Riordan, C. M. (2000). Relational demography within groups: Past developments, contradictions, and new directions. In G. R. Ferris (Ed.), Research in personnel and human resources management (pp. 131-173). Greenwich, CT: JAI Press.

Robert, C., Probst, T. M., Martocchio, J. J., Drasgow, F., \& Lawler, J. J. (2000). Empowerment and continuous improvement in the United States, Mexico, Poland, and India: predicting fit on the basis of the dimensions of power distance and individualism. Journal of Applied Psychology, 85(5), 643-658. http://dx.doi.org/10.1037/0021-9010.85.5.643

Roberts, K. H., \& O'Reilly, C. A. (1979). Some Correlations of Communication Roles in Organizations1. Academy of Management Journal, 22(1), 42-57. http://dx.doi.org/10.2307/255477

Ruef, M., Aldrich, H. E., \& Carter, N. M. (2003). The structure of founding teams: Homophily, strong ties, and isolation among US entrepreneurs. American Sociological Review, 68(2), $195-222$. http://dx.doi.org/10.2307/1519766

Ryan, R. M., \& Deci, E. L. (2003). On assimilating identities to the self: A self-determination theory perspective on internalization and integrity within cultures. In M. R. Leary \& P. J. Tangney (Eds.), Handbook of self and identity (pp. 253-272). NY: Guilford Press.

Sagiv, L., \& Lee, F. (2006). Organizational artifacts: a window to organizational values. Paper presented at the R. Roccas \& L. Sagiv (Chairs), Understanding Social Collectives in Terms of their Values, 18th Meeting of the International Congress of Cross Cultural Psychology. July, Spetses, Greece.

Schaubroeck, J., Lam, S. S., \& Cha, S. E. (2007). Embracing transformational leadership: team values and the impact of leader behavior on team performance. Journal of Applied Psychology, 92(4), 1020. http://dx.doi.org/10.1037/0021-9010.92.4.1020

Schein, E. H. (1990). Organizational culture. American psychologist, 45(2), $109-119$. http://dx.doi.org/10.1037/0003-066X.45.2.109

Schuler, R. S., \& Rogovsky, N. (1998). Understanding compensation practice variations across firms: The impact of national culture. Journal of International Business Studies, 29(1), 159-177. http://dx.doi.org/10.1057/palgrave.jibs.8490030

Schwartz, S. H. (1999). A theory of cultural values and some implications for work. Applied psychology, 48(1), 


\section{3-47. http://dx.doi.org/10.1111/j.1464-0597.1999.tb00047.x}

Schwartz, S. H., \& Bardi, A. (2001). Value hierarchies across cultures taking a similarities perspective. Journal of Cross-Cultural Psychology, 32(3), 268-290. http://dx.doi.org/10.1177/0022022101032003002

Selmer, J., \& De Leon, C. (1996). Parent cultural control through organizational acculturation: HCN employees learning new work values in foreign business subsidiaries. Journal of Organizational Behavior, 17, 557-572. http://dx.doi.org/10.1002/(SICI)1099-1379(199612)17:1+<557::AID-JOB823>3.0.CO;2-0

Shuper, P. A., Sorrentino, R. M., Otsubo, Y., Hodson, G., \& Walker, A. M. (2004). A Theory of Uncertainty Orientation Implications for the Study of Individual Differences Within and Across Cultures. Journal of Cross-Cultural Psychology, 35(4), 460-480. http://dx.doi.org/10.1177/0022022104266109

Smith, K. G., Smith, K. A., Olian, J. D., Sims Jr, H. P., O’Bannon, D. P., \& Scully, J. A. (1994). Top management team demography and process: The role of social integration and communication. Administrative Science Quarterly, 39(3), 412-438. http://dx.doi.org/10.2307/2393297

Smith, P. B. (2004). Acquiescent response bias as an aspect of cultural communication style. Journal of Cross-Cultural Psychology, 35(1), 50-61. http://dx.doi.org/10.1177/0022022103260380

Spreitzer, G. M., Perttula, K. H., \& Xin, K. (2005). Traditionality matters: An examination of the effectiveness of transformational leadership in the United States and Taiwan. Journal of Organizational Behavior, 26(3), 205-227. http://dx.doi.org/10.1002/job.315

Stewart, R., Barsoux, J. L., Kieser, A., Ganter, H. D., \& Walgenbach, P. (1994). Managing in Britain and Germany. New York, St: Martin's Press.

Thomas, D. C., \& Ravlin, E. C. (1995). Responses of employees to cultural adaptation by a foreign manager. Journal of Applied Psychology, 80(1), 133. http://dx.doi.org/10.1037/0021-9010.80.1.133

Thomas, D. C., \& Toyne, B. (1995). Subordinates' responses to cultural adaptation by Japanese expatriate managers. Journal of Business Research, 32(1), 1-10. http://dx.doi.org/10.1016/0148-2963(94)00003-W

Ting Toomey, S. (1988). Managing Intimate Conflict in Intercultural Personal Relationships. In D. D. Cahn (Ed.), Intimate Conflict in Personal Relationships. Hillsdale, NJ: Erlbaum.

Triandis, H. (1998). Vertical and horizontal individualism and collectivism: Theory and research implications for international comparative management. In J. C. Cheng \& R. B. Peterson (Eds.), Advances in international comparative management (pp. 7-36). Stanford, CT: JAI Press.

Triandis, H. C. (1995). Individualism \& collectivism. San Francisco: Westview Press.

Ueno, S., \& Sekaran, U. (1992). The influence of culture on budget control practices in the USA and Japan: An empirical study. Journal of International Business Studies, 23(4), 659-674. http://dx.doi.org/10.1057/palgrave.jibs.8490282

Walumbwa, F. O., Lawler, J. J., \& Avolio, B. J. (2007). Leadership, Individual Differences, and Work-related Attitudes: A Cross-Culture Investigation. Applied psychology, 56(2), 212-230. http://dx.doi.org/10.1111/j.1464-0597.2006.00241.x

Wang, H. C., Fussell, S. F., \& Setlock, L. D. (2009). Cultural difference and adaptation of communication styles in computer-mediated group brainstorming. Proceedings of CHI 2009 (pp. 669-678). NY: ACM Press.

Yan, J., \& Hunt, J. G. J. (2005). A cross cultural perspective on perceived leadership effectiveness. International Journal of Cross Cultural Management, 5(1), 49-66. http://dx.doi.org/10.1177/1470595805050824

Zaidman, N., \& Brock, D. M. (2009). Knowledge Transfer Within Multinationals and Their Foreign Subsidiaries A Culture-Context Approach. Group \& Organization Management, 34(3), 297-329. http://dx.doi.org/10.1177/1059601108330062

Zaltman, G., \& Duncan, R. (1977). Strategies for planned change. New York: Wiley.

\section{Copyrights}

Copyright for this article is retained by the author(s), with first publication rights granted to the journal.

This is an open-access article distributed under the terms and conditions of the Creative Commons Attribution license (http://creativecommons.org/licenses/by/3.0/). 